\title{
MODELOS CONTEMPORÂNEOS DE DEMOCRACIA E O PAPEL DAS ASSOCIAÇÕES
}

\author{
Lígia Helena Hahn Lüchmann
}

\begin{abstract}
RESUMO
O artigo aborda teorias da democracia que, fazendo uso de diferentes argumentos, dão destaque ao papel das associações na promoção de ideais democráticos como participação, igualdade, justiça, legitimidade, deliberação e eficiência. Em que pese as variações teórico-normativas que registram diferenças no tratamento e no valor dado ao papel das associações, é possível extrair, dentre um campo plural de abordagens teóricas, pelo menos três enfoques que apontam relações positivas, senão alternativas, entre as associações e a democracia: o enfoque da democracia participativa, da democracia associativa e da democracia deliberativa. Embora compartilhem a insatisfação com o modelo liberal eleitoral, reclamando, entre outros, do peso competitivo e individual dado à dimensão da participação política, esses modelos democráticos manifestam, além de pontos em comum, diferenças analíticas que merecem atenção. Para expoentes da democracia participativa, o principal argumento acerca da importância democrática das associações está ancorado na tese de que as associações são instrumentos que qualificam a participação direta dos cidadãos, verdadeira essência da democracia. Para a vertente da democracia associativa, as associações são soluções - possíveis e democráticas - para lidar com a administração da complexidade social. Teóricos da democracia deliberativa enfatizam a importância da sociedade civil, preenchida fundamentalmente por associações e movimentos sociais, para gerar poder legítimo na esfera pública. $O$ artigo sugere que a ampliação e o aprofundamento da democracia depende da articulação, não isenta de tensões, entre os pressupostos da participação, da representação, da deliberação e da associação.
\end{abstract}

PALAVRAS-CHAVE: associações; democracia participativa; democracia associativa; democracia deliberativa.

\section{INTRODUÇÃ̃O ${ }^{1}$}

Os problemas e os limites apontados à democracia representativa vêm estimulando o debate e o desenvolvimento de novos modelos teóricos de democracia que ampliam os atores, os espaços, e os sentidos da política. "Democracia participativa", "democracia associativa" e "democracia deliberativa" têm se destacado, entre um leque mais amplo de modelos, como aportes teórico-analíticos valiosos no sentido do questionamento dos pressupostos democráticos que tendem a restringir a ação política a

1 Esse trabalho faz parte do projeto de pesquisa (Bolsa de Produtividade em Pesquisa (PQ) do Conselho Nacional de Desenvolvimento Científico e Tecnológico (CNPq)) intitulado "Associativismo civil, participação e democracia: novas práticas e configurações". Agradeço a leitura atenta e os comentários dos pareceristas anônimos da Revista de Sociologia e Política. determinados atores e estruturas institucionais, dadas como únicas e possíves frente à pluralidade e a complexidade social. Dessa forma, surgem como alternativas críticas às teorias "realistas" 2 que concebem a democracia como um mecanismo de escolha de líderes políticos mediante a competição, entre os partidos, pelo voto, equiparando a dinâmica política ao jogo do mercado (MACPHERSON, 1978). Para seus críticos, esse modelo "liberal" reduz a democracia a um mecanismo de escolha dos representantes políticos na formação dos governos e parlamentos

\footnotetext{
2 Entre as teorias "realistas" da democracia, sobressai-se a teoria do "elitismo competitivo" de Schumpeter e o modelo pluralista de Dahl. Segundo Held (1987), se o elitismo de Schumpeter enfatiza a concentração de poder nas mãos das elites políticas, a teoria pluralista enfatiza a ação dos grupos de interesses no processo de competição pelo poder. Para Macpherson (1978), essas teorias formam o modelo do "equilibrio" ou do "elitismo pluralista".
}

Rev. Sociol. Polít., Curitiba, v. 20, n. 43, p. 59-80, out. 2012 
cuja base de legitimidade é limitada ao processo eleitoral.

É exatamente tendo em vista a recuperação de uma dimensão normativa da democracia que, ao acusar a redução da política a uma lógica individualista e competitiva, desenvolve-se, a partir dos anos de 1960, uma concepção "participativa" ou "republicana" de democracia, ancorada no ideal da participação direta dos cidadãos nos assuntos de interesse da coletividade. À luz de teóricos clássicos como Rousseau e John Stuart Mill, esse referencial enfatiza o caráter de autodeterminação dos cidadãos na condução da coisa pública, por um lado, e a dimensão pedagógica e transformadora da participação política, por outro. Para os autores formuladores do modelo da democracia participativa, Rousseau é um dos principais expoentes da defesa da autoridade soberana do povo em decidir o que é melhor para a coletividade. De acordo com Held (1987), na "versão de Rousseau, a idéia de autogoverno é apresentada como um fim em si mesmo; segundo ele, uma ordem política que oferece oportunidades para a participação na elaboração dos negócios públicos não deveria apenas ser um Estado, mas um novo tipo de sociedade" (idem, p. 68; grifos no original).

$\mathrm{O}$ questionamento acerca das premissas liberais que estão centradas no caráter instrumental, elitista e competitivo da democracia eleitoral também se estende ao papel e ao lugar das associações nos processos políticos. Fung (2003) ressalta como, na perspectiva democrática liberal ancorada na tese da maximização das escolhas individuais, as associações são vistas como um componente da liberdade individual, rejeitando qualquer atuação mais substantiva na esfera da política em função dos riscos de ampliação, via demandas associativas, do poder do Estado sobre a sociedade, ou da feudalização do Estado administrativo na sua captura por interesses organizados (COHEN \& ROGERS, 1995).

De diferentes maneiras, abordagens teóricas alternativas da democracia procuram extrair elementos mais substantivos no que diz respeito aos benefícios democráticos das associações, não se conformando com as premissas que apontam a liberdade individual e a competição no mercado como únicos recursos de sua justificação. Navegando na mesma corrente, essas abordagens compactuam, de diferentes maneiras, com os princípios da deliberação, da participação e da importância das associações, sem romperem com os pressupostos gerais da representação eleitoral. Thompson (2008), por exemplo, mostra como a virada em direção à democracia deliberativa não tem significado uma desconsideração à teoria participativa. Antes do que transcender a democracia participativa, muitos democratas deliberativos procuram expandi-la, adicionando a deliberação na lista de atividades políticas que conformam o ideário da participação (idem, p. 512). Da mesma forma, autores da democracia participativa reconhecem a importância dos pressupostos da deliberação e da associação tendo em vista a ampliação da participação no modelo da representação política de base eleitoral.

Assim, a proposta deste artigo não é enquadrar autores em modelos, mas procurar identificar os principais argumentos que traduzem a justificativa da importância e do papel dado às associações por essas três vertentes teóricas da democracia ${ }^{3}$. No caso da democracia participativa, o foco central é o resgate dos ideais de autogoverno e de soberania popular por meio da participação dos cidadãos nos processos de discussão e de decisão política. Com efeito, visando a aprimoramento da democracia liberal, os participacionistas incorporam - ou combinam - pressupostos da democracia direta no interior da democracia representativa, dando ênfase à inclusão dos setores excluídos do debate político e à dimensão pedagógica da política. Para Pateman (1992), a participação é educativa e promove, por meio de um processo de capacitação e conscientização (individual e coletiva), o desenvolvimento da cidadania, cujo exercício configura-se como requisito central para a ruptura com o ciclo de subordinação e de injustiças sociais. A participação desenharia um outro ciclo, agora virtuoso, ancorado nas relações positivas entre a ampliação dos espaços e atores participativos, na mudança da consciência política, e na redução das desigualdades sociais (MACPHERSON, 1978). A

\footnotetext{
3 Trata-se, portanto, de um recorte no tema das teorias alternativas da democracia. Além disso, esse trabalho não tem a pretensão de apresentar o debate e os autores que analisam diferentes efeitos democráticos das associações, incluindo, por exemplo, os trabalhos que, seguindo uma perspectiva neotocquevilliana, dão centralidade ao conceito de capital social (PUTNAM, 1995; 1996). Para essa análise, ver Warren (2001).
} 
ênfase na democracia direta, ou na ideia de autogoverno revela o peso, digamos indireto, dado às associações se comparado à perspectiva da democracia associativa.

A vertente teórica da democracia associativa assume, de maneira mais enfática, e como revelado em sua própria denominação, o papel das associações nos processos de aprofundamento e de ampliação da democracia. Aqui, os argumentos em defesa da impotância das associações à democracia giram em torno da constatação dos diagnósticos acerca dos limites dos atores e das instituições políticas tradicionais (estados e partidos) frente ao acelerado aumento da complexidade dos fenômenos sociais. Para os seus autores, as associações figuram como importantes remédios democráticos ( $i$ ) no sentido de superação do individualismo; (ii) da democratização dos mecanismos de representação e/ou (iii) de uma atuação política mais diretamente voltada para a resolução dos problemas sociais, promovendo maior eficiência governamental (HIRST, 1994; 2001; COHEN \& ROGERS, 1995; ELSTUB, 2007; 2008).

A democracia deliberativa, por seu turno, ao acusar as fragilidades da democracia representativa e a redução da legitimidade do processo decisório ao resultado eleitoral, advoga que a legitimidade das decisões políticas advém de processos de discussão que, orientados pelos princípios da inclusão, do pluralismo, da igualdade participativa, da autonomia e do bem-comum, conferem um reordenamento na lógica do poder político do modelo democrático liberal. Aqui, as associações recebem abrigo no conceito de sociedade civil, e, embora também se ventilem diferenças e divergências quanto ao seu lugar político, são consideradas como atores mais diretamente vinculados aos interesses e problemas da vida social. As associações também seriam responsáveis pela constituição de esferas públicas que problematizam, oxigenam e alteram os mecanismos tradicionais de formulação das regras e políticas que regulam e afetam a vida social.

Ao procurar apresentar os principais argumentos das teorias democráticas que colocam as associações no horizonte da ampliação democrática nas sociedades contemporâneas, o artigo busca apontar, tendo em vista a pluralidade e a complexidade social, uma perspectiva descentrada de política e de sociedade que, diferente do registro de um único corpo ou um conjunto pré-definido de instituições responsáveis pelos processos político-decisórios, reconhece múltiplos centros, práticas e instituições que conformam o processo democrático ${ }^{4}$. Nessa perspectiva, o artigo reconhece não apenas a importância dos diferentes tipos de ação política - e as tensões entre eles - a exemplo da participação direta, dos processos deliberativos e da representação eleitoral, como diferentes contribuições (ou efeitos) democráticos das associações, conformando o que Warren (2001) denomina de "ecologia democrática das associações".

$\mathrm{O}$ artigo está dividido em três partes. $\mathrm{Na}$ primeira parte, justifica-se, de maneira breve, a escolha do termo "associação", propondo uma perspectiva que contemple a pluralidade e as desigualdades desse campo, ou seja, a complexidade dessas práticas sociais, e que atente à necessidade de reconhecer as associações em seus aspectos multi-relacionais. Na segunda parte, apresenta-se os principais argumentos, nas três vertentes teóricas da democracia (participativa, associativa e deliberativa), que dão suporte às avaliações acerca da importância democrática das associações. Na terceira e última parte, e a guisa de conclusão, sugere que a ampliação e o aprofundamento da democracia dependem da articulação, não isenta de tensões, entre os pressupostos da participação, da representação e da deliberação, levados a cabo - em diferentes lugares e seguindo múltiplos caminhos - por indivíduos, associações e instituições.

\section{SOBRE O SIGNIFICADO DE “ASSOCIA- ÇÃO"}

Certamente, há uma grande dificuldade para uma definição precisa de "associação", ao ponto

\footnotetext{
4 Seguindo a compreensão de Young (2001) para quem o processo democrático não pode ser identificado ou reduzido a uma instituição ou um conjunto de instituições políticas, como os órgãos do Estado ou as esferas legislativas, etc. A ação política e as práticas comunicativas que sustentam os processos de decisão democráticos ocorrem em diferentes fluxos e espaços e entre diferentes setores e atores sociais. Pensar a dimensão da inclusão enquanto critério central para a ampliação e o aprofundamento democrático significa, portanto, pensar e reconhecer a importância de diferentes espaços, atores e instituições políticas, sejam processos deliberativos, práticas autônomas do ativismo político, e instituições da democracia representativa.
} 
de perguntarmo-nos se seria possível, frente à multiplicidade de práticas associativas, estabelecer características gerais que permitam algumas distinções sem recair em reduções e simplificações. Essa dificuldade pode ser encontrada em diferentes perspectivas teóricas, e está alicerçada nas várias interpretações acerca da importância das associações para a vida democrática das sociedades. A teoria do capital social de Putnam (1995; 1996), por exemplo, e seguindo uma tradição tocquevilleana, contempla, majoritariamente, as associações "face-a-face", ou as associações secundárias, a exemplo de clubes de futebol, corais, grupos de escoteiros, associações comunitárias etc ${ }^{5}$. Teóricos da democracia associativa como Cohen e Rogers (1995) privilegiam, em sua análise, as grandes associações - sindicatos e federações, por exemplo - que representam amplos setores sociais e mobilizam estruturas e recursos que extrapolam a dimensão local. No caso dos estudos sobre os movimentos sociais, o foco recai sobre aqueles grupos e associações que contestam a ordem social. Para a teoria da sociedade civil habermasiana, a vinculação entre as associações e o mundo da vida desqualifica organizações que estão mais diretamente inseridos nos campos político e econômico, a exemplo dos partidos e sindicatos ${ }^{6}$.

Em que pesem essas diferenças, há uma noção mais ou menos comum quando estamos falando de associação. Recuperando os principais autores que contribuíram para a análise acerca da importância democrática das associações, Warren (2001) ressalta a influência de Tocqueville para certa sedimentação em sua concepção moderna, na medida em que esse autor via as associações

\footnotetext{
5 Uma influente vertente analítica acerca do associativismo tem revigorado os pressupostos encontrados na obra $A$ democracia na América, de Alexis de Tocqueville. Estudos como os de Almond e Verba (1963) e Verba e Nie (1972) encontraram diferenças consistentes no comportamento cívico - maior interesse em política, maior compromisso, confiança e eficácia política etc. - entre os indivíduos que participam e os que não participam em associações voluntárias, com notável vantagem para os primeiros. Robert Putnam é uma referência central nessa linha interpretativa, fundamentalmente por seus estudos que apontam o peso do capital social, e, mais especificamente, das associações, para a promoção de redes de engajamento cívico que são centrais para a vida democrática.

6 Uma apresentação mais detalhada dessas diferentes perspectivas encontra-se em Lüchmann (2011).
}

secundárias ${ }^{7}$, ao contrário dos vínculos primários, como ações coletivas benéficas ao cultivo da sensibilidade ética de um "auto interesse bem compreendido", desenvolvendo novas formas democráticas de interação. Warren (2001, p. 42) aponta duas características do associativismo que são centrais para Tocqueville, quais sejam, a existência de uma relativa igualdade social entre os seus integrantes e o caráter de voluntariedade na constituição de relações consensuadas que alteram a sensibilidade ética dos seus membros.

Nessa perspectiva, o sentido de associações cobre majoritariamente aqueles tipos de vínculos associativos que são frutos de escolhas pessoais e que apresentam laços mais fracos (se comparados com as associações familiares, por exemplo) e maior grau de autonomia (se comparados com grupos e organizações sindicais e profissionais, com estruturas mais hierárquicas em que os membros são relativamente anônimos entre si). Relações mais igualitárias e voluntarismo são, portanto, duas características que têm marcado a definição de associação, injetando certo paroquialismo no conceito ao negligenciar a importância democrática das associações tanto primárias (mais estreitas), quanto terciárias (idem, p. 40) ${ }^{8}$. Além disso, essa perspectiva apresenta limites frente a uma concepção bipolar de sociedade ${ }^{9}$, em perceber

\footnotetext{
7 De acordo com Warren (2001), parece que foi Charles H. Cooley em Human Nature and Social Order (COOLEY, 1983) quem primeiro diferenciou os três tipos de associações de acordo com a natureza dos laços e do grau de autonomia. Assim, famílias e amizades são redes de associação primária, pois desenvolvem relações mais próximas e íntimas. As associações secundárias, embora também próximas, distanciam-se do tipo de laços das "associações primárias" e voltam-se para relações que transcendem o mundo individual, como os grupos cívicos, os clubes, as associações religiosas, entre tantas outras. As "associações terciárias" seriam os grupos de interesses e profissionais, nos quais os membros são relativamente anônimos entre si e têm pouco em comum, a não ser uma proposta específica a que perseguem (WARREN, 2001, p. 39).

8 Entra aqui também o reconhecimento de que muitas associações não são boas para a democracia, como determinados grupos privados, grupos racistas, de ódio, e muitos grupos de interesses poderosos, que fazem jus às suspeitas de facçiosismo levantadas por Madison e Rousseau em suas preocupações com o ideal do bem comum (idem, p. $10)$.

9 Seguindo a análise de Warren (2001, p. 32), Toqueville trabalhou com um modelo bipolar em sua análise das rela-
} 
tanto as relações de desigualdade e de poder no interior do campo associativo, quanto as relações entre as associações e outras formas de organização, como os estados e os mercados, na formação de complexas redes e parcerias por meio da provisão de serviços sociais, de financiamentos públicos e privados, do desenvolvimento de projetos nas diferentes áreas sociais, de inserção de lideranças sociais nos aparelhos do Estado etc.

De acordo com Warren (idem), da mesma forma que encontramos relações associativas nos estados e nos mercados, encontramos relações políticas e mercadológicas nas associações: "Nenhuma instituição pode atuar de forma pura por meio de operações de mercado ou do comando hierárquico. Da mesma forma, poucas associações, devido aos seus envolvimentos com o poder e o dinheiro, exibem, de forma pura, as qualidades consensuais e voluntárias das relações associativas" (idem, p. 54). O reconhecimento de que as associações interagem com estados, mercados e com relações de intimidade (idem, p. 58) oferece reforço à ideia de que o campo associativo é amplo e heterogêneo, envolvendo tanto os grupos sociais nas diferentes esferas (social, cultural, econômica e política), quanto os diferentes formatos, recursos e intenções. A depender de suas características - liberdade de pertencimento, objetivos e recursos - os diferentes tipos de associações podem promover diferentes efeitos democráticos (ou antidemocráticos) que, no seu conjunto, conformam a "ecologia democrática das associações" (ibidem). Algumas podem ser importantes para o exercício da governança, outras para desenvolver habilidades cívicas, desenvolver atividades contestadoras e/ ou de resistência, promover encontros sociais etc. A ideia de "ecologia" está assentada na premissa de que o problema de generalizar os benefícios democráticos das associações é o de apontar efeitos onde eles não existem. Além disso, as

ções entre Estado e sociedade civil e concebeu os efeitos institucionais das associações dentro desse modelo, que assume dois meios básicos de organização social: o coercitivo, legal e admistrativo - do Estado; e o meio social das normas, hábitos culturais, discussão e acordo, que caracterizam as relações não estatais. Nessa visão, o poder recai sobre o Estado, e as interações sociais são encontradas na sociedade, que assimila, sem qualificar suas especificidades estruturais, o mercado. associações "podem produzir efeitos similares por diferentes razões" (idem, p. 141). E ainda, outro problema pode ser o fato de se ignorar possíveis benefícios democráticos em associações que são descartadas a priori em função de perspectivas teóricas e ideológicas ${ }^{10}$.

Como veremos a seguir, três vertentes teóricas da democracia dão destaque ao papel democrático das associações. Embora a carência de definições mais rigorosas acerca do significado de associações, percebe-se o predomínio, na vertente da democracia participativa, das "associações secundárias", com destaque aos movimentos sociais e comunitários. O caráter de autonomia e voluntariado também se destaca na vertente teórica da democracia deliberativa, que coloca as associações autônomas, voluntárias e/ou os movimentos sociais como atores centrais do conceito de sociedade civil. Já a vertente da democracia associativa apresenta um quadro mais amplo de associações, reconhecendo a importância de organizações mais estruturadas e abrangentes, como sindicatos e associações profissionais.

\section{DEMOCRACIA PARTICIPATIVA E O EXERCÍCIO DA PARTICIPAÇÃO DOS CIDADÃOS}

A incorporação das associações no interior do campo teórico da democracia compõe o quadro mais amplo de argumentos críticos ao modelo da democracia liberal. De acordo com Fung (2003), a perspectiva liberal da democracia entende as associações como componentes das liberdades individuais. Uma vez que a democracia diz respeito às garantias dos direitos individuais, entre eles, $o$ direito de formar grupos e organizações tendo em vista a satisfação de interesses, a democracia contribui "naturalmente" para a constituição das associações. Para além disso, qualquer exigência de uma atuação política mais substantiva por parte das associações significaria colocar em risco a própria democracia, seja por pressionar o Estado, estendendo as suas funções e atividades, seja por

\footnotetext{
${ }^{10}$ Um exemplo interessante é o estudo de Baggetta (2009) sobre os grupos de corais nos EUA. Mesmo sendo grupos com objetivos bem específicos e distantes de estarem voltados para a criação de oportunidades cívicas, eles apresentam um importante potencial para tal, ao promoverem interação, experiência gerencial e conexão com outras instituições.
} 
intervir negativamente nas liberdades individuais. Assim, para o liberalismo, o argumento geral acerca das relações entre associações e democracia gira em torno do princípio da garantia das liberdades individuais, entre elas a liberdade de associação e a liberdade do mercado, tido como agente mais eficiente para a alocação de recursos na sociedade. Aqui, como analisam Cohen e Rogers (1995), são toleradas as associações voluntárias que não ameaçema eficiência do mercado ou das liberdades fundamentais dos não membros. É esse argumento que permite diferenciar o potencial democrático das associações, revelado por sua atuação no sentido de aliviar as pressões e demandas que implicam a ampliação dos gastos e funções governamentais ${ }^{11}$.

Mesmo considerando-se as diferenças de enfoque e de argumentos, é possível encontrar um conjunto suficiente de elementos que caracterizam a democracia participativa, embora também seja relevante constatar, novamente, suas articulações com outras vertentes e perspectivas alternativas à democracia liberal.

Segundo Macpherson (1978), a ideia de democracia participativa surgiu no contexto dos movimentos estudantis durante os anos de 1960, difundindo-se para outros setores, como as classes trabalhadoras, que passam a demandar maior controle e melhores condições de trabalho durante as décadas de 1960 e 1970. De maneira geral, os democratas participativos acusam o pressuposto equivocado da perspectiva democrática contemporânea ${ }^{12}$ que reduz a participação dos cidadãos ao momento eleitoral da escolha dos representantes políticos. Com efeito, esses

11 Assim, os clubes e associações de caridade são bem vistos, por atuarem no sentido de assumir atividades que aliviam as demandas por aumento das atividades do Estado, diferente dos sindicatos, que aumentam as pressões sobre o Estado e interferem na liberdade do mercado (COHEN \& ROGERS, 1995).

12 Denominada de "democracia de equilíbrio" ou "modelo elitista pluralista", por Macpherson (1978), e de "teoria da democracia contemporânea”, por Pateman (1992). De acordo com Pateman, para essa teoria, a democracia é "um método político ou uma série de arranjos institucionais a nível nacional. O elemento democrático característico do método é a competição entre os líderes [elite] pelos votos do povo, em eleições periódicas e livres" (idem, p. 25). Schumpeter (1984) é a referência central. teóricos criticam a concepção que limita o âmbito da democracia a um arranjo ou método de escolha dos líderes políticos e o âmbito do político aos espaços e atores que exercem a atividade política por meio da autorização dada pelo processo eleitoral. De acordo com Macpherson (idem), a democracia é muito mais do que um método político; ela é um tipo de sociedade, ou "um conjunto inteiro de relações recíprocas entre as pessoas que constituem a nação ou outra unidade" (idem, p. 13). A extensão e a ampliação do termo "político" é ressaltada por Pateman (1992) ao analisar processos participativos em outros lugares que não o Estado, como é o caso do espaço industrial. Assim, em consonância com o ideal de ampliação do político e da democracia, esses teóricos apontam para a importância da ampliação e da diversificação da participação. A premissa geral, seguindo a perspectiva de Rousseau, é a de que os cidadãos são ao mesmo tempo os formuladores e os seguidores de suas leis. Democracia significa, então, devolver aos cidadãos o exercício da atividade política que foi alienada, ou transferida, nas modernas democracias, aos representantes eleitos. Com efeito, esse ideal democrático está assentado no princípio de autogoverno dos cidadãos, visando desqualificar a ideia de que a apatia política é um fenômeno abrangente e natural da vida social.

De acordo com Barber (1984), a democracia não significa o governo da maioria e nem a regra da representação, e sim o autogoverno. Sem a atuação ativa dos cidadãos, resta apenas elites ou política de massas (idem, p. 211). Uma democracia forte, como nomeia a sua perspectiva democrática ("Strong Democracy"13), requer uma concepção forte de cidadania que não se satisfaz com a dimensão passiva e legal do modelo representativo liberal. Para Barber, "cidadania" significa participação ativa na vida pública, o envolvimento com os outros na constituição de um engajamento comum. Por meio da participação, a cidadania oferece medidas que permitem reorientar as necessidades particulares dos indivíduos em direção a fins públicos (idem, p. 224). Seguindo, como os autores anteriores, a perspectiva de

13 Modelo democrático pautado na realização da política como atividade autônoma levada a cabo por indivíduos mobilizados para controlar as suas próprias vidas e contribuir para a sua comunidade (BARBER, 1984, p. 296). 
Rousseau, Barber enfatiza a relação entre o indivíduo e a coletividade, relação essa que proporciona o alargamento das ideias e interesses em direção ao bem comum. Com efeito, o aspecto pedagógico da participação é aqui reiterado, na medida em que essa cidadania forte, ancorada em valores comuns compartilhados, só pode florescer onde a civilidade é reforçada por processos educativos dados pela participação.

Embora a democracia participativa não signifique uma ruptura com o modelo eleitoral, a complementariedade e a compatibilidade com esse modelo revelam mais do que uma acomodação, na medida em que visam impactar positivamente o conjunto das instituições políticas em direção a uma maior aproximação com o ideal de autogoverno. Seja alargando os espaços da participação, seja propondo processos decisórios piramidais de articulação entre participação e representação, o certo é que, de alguma maneira, a introdução da participação, para essa vertente, influencia relações de poder e hierarquias, propiciando a formação de cidadãos mais críticos e interessados na coisa pública.

Para Pateman, "somente se o indivíduo tiver a oportunidade de participar de modo direto no processo de decisão e na escolha de representantes nas áreas alternativas é que, nas modernas circunstâncias, ele pode esperar ter qualquer controle real sobre o curso de sua vida ou sobre o desenvolvimento do ambiente em que ele vive" (PATEMAN, 1992, p. 145). De outra forma, prossegue a autora, "é de se duvidar que o cidadão comum chegue algum dia a se interessar por todas as decisões que são tomadas a nível nacional da mesma forma que se interessaria por aquelas que estão mais próximas dele" (idem, p. 146). O reconhecimento da necessidade de manter, em alguma medida, os pressupostos do modelo representativo eleitoral é também corroborado por Macpherson, ao anunciar que, frente à dimensão, quantidade e complexidade dos processos de decisão política, "nada podemos sem políticos eleitos" (MACPHERSON, 1978, p. 101). Esse autor ventila a possibilidade de ampliação da participação se forem removidos os principais obstáculos a uma verdadeira democracia participativa, quais sejam, a diminuição da desigualdade econômica e social e a mudança da autoimagem do povo "do ver-se e agir como essencialmente consumidor ao ver-se e agir como executor e desfrutador da execução e desenvolvimento de sua capacidade" (idem, p. 102). Sem esses dois requisitos, inviabiliza-se o modelo democrático-participativo em dimensões que ultrapassem a esfera local ${ }^{14}$.

A reativação da cidadania por meio da participação direta é aqui, portanto, o foco central. É nessa perspectiva que, incorporando características da teoria deliberativa, o trabalho de Fung e Wright (2001), ao reivindicar um modelo que os autores denominam de "governança participativa empoderada" 15 , parece se enquadrar bem na moldura mais ampla da democracia participativa, na medida em que aspira o aprofundamento e a extensão da participação dos cidadãos ordinários nas políticas que afetam as suas vidas. Tendo como referência empírica experiências públicas de participação em diferentes países 16 que denominam de "democracia deliberativa empoderada" (idem), os autores analisam como essas práticas alternativas podem revelar o aprofundamento democrático, seja por permitirem uma efetiva resolução de problemas, no sentido de trazer resultados que dizem respeito às necessidades concretas dos cidadãos, seja na possibilidade de proporcionarem maior igualdade, fundamentalmente por incorporarem os cidadãos mais pauperizados e excluídos dos processos de decisão política; ou ainda por irrigarem processos de ampliação e aprofundamento da participação (idem, p. 28). Ademais, além de permitir a participação direta nos processos de discussão e de resolução dos problemas nas diferentes áreas sociais, a participação constitui-se como "escola de cidadania", ao possibilitar o desenvolvimento de cidadãos cívicos, melhor informados e habilitados para a atuação política (idem, p. 29).

14 Para Barber, as exigências da participação não se restringem a esferas locais, estendendo-se para os planos regional e nacional, a exemplo de encontros regionais e nacionais por meio das novas tecnologias de comunicação, da oferta de serviços - publicações e materiais - de informação e educação cívica, referendos com amplos debates e participação, votação eletrônica sobre questões públicas via debates, entre outros (BARBER, 1984).

15 "Empowered Participatory Governance" (EPG).

16 A exemplo dos "Neighborhood Councils" em Chicago, os "Workers Education Centers" em Wiscousin, os "Habitat Conservation Plans" nos EUA, o "orçamento participativo" em Porto Alegre e a "governança local" em Kerala, India. 
Com efeito, o foco na participação-e, portanto, na democracia direta - dos cidadãos nos espaços de discussão e formulação de políticas públicas é a característica central da democracia participativa. Para esse modelo, o aprofundamento da democracia implica a criação de instituições públicas que incorporem a participação dos indivíduos nos processos de decisão. As associações são importantes, embora não recebam um tratamento ou status central, a exemplo, como veremos, do modelo da democracia associativa. De acordo com Fung (2003), as associações não são substitutas da participação individual, embora sejam muito importantes para a sua criação e qualificação. De maneira geral, as reformas em direção à constituição de oportunidades participativas são decorrentes da pressão de associações e de movimentos sociais. Assim, as associações jogam um importante papel na defesa de instâncias participativas, resistindo às recorrentes tentativas de recentralização e de controle governamental. Elas equipam e mobilizam os indivíduos, principalmente nas áreas mais pobres e fragilizadas, provendo informação e habilidades necessárias para um engajamento cidadão junto aos espaços democráticos participativos e às instituições políticas da democracia eleitoral.

De acordo com Macpherson (1978), o rompimento com o ciclo vicioso da desigualdade e da não participação pode ocorrer, entre outras possibilidades, por meio de movimentos e organizações comunitárias, ou de associações que exercem pressão para a mudança das condições sociais, atraindo para a participação política, sobretudo, os setores mais empobrecidos da população e que "estiveram por muito tempo politicamente apáticos" (idem, p. 106) ${ }^{17}$.

17 Algumas experiências de orçamento participativo (OP), no Brasil, podem ser consideradas exemplares, nesse sentido. Vários estudos apontam a capacidade do Orçamento Participativo em mobilizar a participação de indivíduos de setores populares (FEDOZZI, 1996; AVRITZER, 2002). Em análise, sobre essa capacidade de inclusão de setores da população com baixa renda e escolaridade, Lüchmann e Borba (2008) sugerem que, além do fato de tratar de questões que afetam de forma mais direta os setores mais carentes e dependentes dos serviços estatais, o OP, ao obedecer à organização territorial das cidades, mobiliza e incorpora o associativismo comunitário ou de bairro, considerado a principal forma de organização coletiva das populações mais pobres. Assim, a regionalização dos espaços de discussão do OP operacionaliza a participação dos indivíduos
Assim, para a vertente da democracia participativa, o principal argumento acerca da importância democrática das associações está ancorado na tese de que as associações são espaços ou instrumentos que qualificam a participação dos indivíduos como cidadãos, verdadeira essência da democracia. Associações provêem informações, contribuem para a criação de espaços de participação, empoderam indivíduos para uma participação mais ativa e qualificada junto às instituições participativas. O foco sobre a participação dos indivíduos no exercício de funções deliberativas e de administração e provisão de serviços públicos garante, embora em combinação com as instituições da democracia representativa, o avanço da democracia direta, ou da radicalização da democracia como um ideal de autogoverno. Cabe às associações secundárias pavimentar os caminhos para o alcance desses ideais, contribuindo para a promoção do desenvolvimento individual, entre outros benefícios democráticos ${ }^{18}$.

A ênfase na participação e na inclusão, nesse modelo democrático, negligencia aspectos relacionados com a qualidade da participação, e como corolário, com as relações entre participação e representação. De fato, quando olhamos as experiências de participação institucional, a exemplo dos orçamentos participativos, e que são também enquadrados, como analisam Urbinati e Warren (2008) como democracia participativa ou democracia direta, esses termos não condizem, em boa medida, com uma realidade caracterizada por uma pequena quantidade de indivíduos efetivamente ativos. Assim, como analisa Warren (2008), enquanto a noção de democracia participativa sugere o ideal do autogoverno por

em suas regiões e mobiliza, em boa medida, a atuação de um tipo de associação (de moradores) na discussão dos problemas e na escolha de delegados e conselheiros, por meio de um desenho que combina participação e representação.

18 Warren (2001) desenvolve as diversas características que conformam os três tipos de efeitos democráticos que são, potencialmente, produzidos pelas associações, quais sejam: efeitos no desenvolvimento individual em direção à promoção de julgamentos autônomos; efeitos nas esferas públicas, tendo em vista a formação de opinião e de julgamentos públicos e efeitos político-institucionais, seja ampliando e qualificando a representação política, seja cooperando para formas alternativas de governança. 
meio da participação, uma característica central desses processos participativos é a sua natureza representativa. Nessa perspectiva, antes de serem medidos pela quantidade dos indivíduos participantes, esses processos devem ser avaliados pela natureza e pela qualidade de representação democrática alcançada. De acordo com o autor, as teorias da democracia participativa não estão equipadas para prover análises nesse sentido (idem). Da mesma forma, teorias da democracia deliberativa reclamam da ausência, no campo democrático participativo, de ferramentas analíticas que avaliem a qualidade da participação.

IV. DEMOCRACIA ASSOCIATIVA: AS ASSOCIAÇÕES COMO SUJEITOS DA PARTICIPAÇÃO POLÍTICA

$\mathrm{Na}$ vertente teórica da "democracia associativa", e como indicado no próprio termo, as associações assumem um papel político central. Se para a democracia participativa as associações contribuem para a participação direta dos indivíduos, nutrindo e irrigando a cidadania, nesse modelo elas tornam-se os agentes por excelência, ao lado de governos e partidos, de atuação política. Poderíamos dizer que, aqui, as associações substituem os indivíduos como sujeitos centrais da democracia. De acordo com Elstub (2008), a democracia associativa pode ser definida como um modelo de democracia participativa no qual o ideal de autogoverno é preenchido pelos grupos e associações.

De maneira geral, e também em que pese as diferenças entre os seus expoentes, o ponto de partida comum do argumento acerca da importância das associações diz respeito às deficiências dos modelos de formulação e de decisão política de base eleitoral perante as mudanças na ordem social, política e econômica das sociedades contemporâneas. Os principais argumentos para a defesa desse ideário democrático estão ancorados, portanto, na tese da debilidade teórica para lidar com as mudanças societais e, como corolário, com o reconhecimento de que os repertórios, os espaços e as instituições políticas existentes não atendem aos novos desafios do mundo contemporâneo, competitivo e globalizado (BADER, 1995, p. 1).

Nesse contexto, os desafios superpõem-se, aprofundando as debilidades do Estado em lidar com a complexidade e a pluralidade dos problemas e demandas sociais. Bader (idem), por exemplo, apresenta uma lista de questões que precisam ser enfrentadas, entre elas: como combinar os desafios do individualismo e da diversidade cultural sem a perda de uma unidade mínima baseada na confiança e na solidariedade? Como lutar contra a pobreza e as desigualdades estruturais tanto em termos globais como no interior dos estados nacionais? Como prevenir os desastres ecológicos, as guerras, os genocídios e a limpeza étnica? Como sustentar políticas de bem estar social sob as condições de extrema competitividade? E ainda, como lidar com a crescente perda de "accountability" democrática dos estados burocráticos (idem, p. 2)?

Alguns indicadores dão sentido à ideia de complexidade social como um aumento no número e nas variações das relações e dos elementos que constituem as sociedades atuais, e que tem levado ao declínio das capacidades e habilidades dos estados-nacionais em administrar as diferentes demandas sociais e, como corolário, às justificativas acerca da importância das associações para o aprofundamento da democracia (ELSTUB, 2008, p. 103). Em primeiro lugar, o aumento da pluralidade social, com a diversificação de grupos, setores, identidades e demandas sociais. Como conseqüência, uma crescente percepção de que as esferas da representação e da gestão políticas são excludentes, fundamentalmente em se considerando os grupos historicamente oprimidos e/ou subordinados, seja pelo recorte de classe, de gênero, de etnia, de idade, entre outros, e a depender da configuração de cada realidade; seja da maior ou menor combinação entre essas condições e identidades sociais. Em segundo lugar, o aspecto do tamanho das sociedades, cujas populações, dispersas sobre amplos e diversos territórios, encontram remotas possibilidades de participar em processos de decisão política centralizados e burocratizados (idem). A crescente necessidade de conhecimento especializado e o fenômeno da globalização são também elementos centrais na constituição de um quadro de complexidade social, por meio da expansão e da diversificação tecnológica, da ampliação da competitividade dos mercados em escala global, do aumento dos problemas e demandas ambientais, e que requerem articulações políticas em âmbitos globais, ao mesmo tempo em que novas articulações regionais e locais.

Uma das referências deste debate, Paul Hirst (1994; 2001) analisa como as mudanças no mundo 
contemporâneo (sociedades pós-liberais), onde o escopo do governo não é mais tão claro, desenham uma sociedade na qual "a divisão entre as esferas pública e privada e as formas de accountability particular a cada uma delas está gravemente comprometida" (HIRST, 2001, p. 17). Quadros multivariados de internacionalização, regionalização e de localização das relações econômicas, políticas e sociais desafiam a constituição de novas instituições de coordenação e regulação.

Entre as mudanças sofridas, o autor destaca os processos de privatização e de comercialização que transpassam as fronteiras do Estado e do mercado, por meio, entre outros, da atuação publicadas das organizações empresariais, embora desprovida de controle democrático. Além disso, a diversificação das demandas sociais e a complexificação das políticas públicas sobrecarregam as possibilidades de controle efetivo por parte dos governos convencionalmente eleitos. A pluralização da sociedade, dos grupos e as mudanças na extensão da individualização influenciam as demandas pela provisão de serviços públicos até então uniformizados e hierarquicamente gerenciados pela burocracia administrativa estatal. Frente a essa realidade, de acordo com o autor, a democracia associativa é a única doutrina política bem adaptada para lidar com os problemas da accountability democrática em uma sociedade culturalmente diversificada (idem, p. 21). Nessa proposta, as estruturas de autoridade seguem modelos federalizados e plurais, sendo que o poder deve ser dividido não apenas territorialmente, mas por funções em domínios específicos. Assim, a democracia associativa teria duas características centrais: ela permitiria construir e transformar as divisões entre Estado e sociedade, e promoveria a governança democrática nos âmbitos público e privado, restringindo e alterando as hirarquias e oferecendo um novo modelo de eficiência organizacional (idem, p. 74).

De acordo com o autor, a proposta de democracia associativa, nesse contexto, pode ser entendida como um terceiro caminho original entre o individualismo do mercado livre e o controle centralizado do Estado. Embora reconheça que a ideia de "associacionalismo" não seja nova ${ }^{19}$, o

19 Hirst (1994) resgata um conjunto de autores do século XIX e início do século XX que abordaram a questão do autor propõe a necessidade de uma revisão tendo em vista a sua acomodação - e não substituição à democracia representativa liberal e às condições dadas pela pluralidade social. Por meio das associações, Hirst alega que é possível construir processos de governaça econômica e governança em questões sociais tendo em vista garantir a liberdade individual e o bem estar social (HIRST, 1994, p. 19). Nessa proposta, a democracia associativa limitaria o individualismo e promoveria a multiplicação de distintos domínios de autoridade, cabendo ao Estado ceder funções e criar mecanismos de financiamento público, tendo em vista garantir a atuação pública das associações como corpos voluntários que exercitam accountability, tanto internamente, quanto junto ao poder público.

Hirst parte do pressuposto de que não são os indivíduos e nem certa ideia de sociedade civil dispersa e formada por grupos periféricos que vão garantir, frente a um mundo econômico operado por corporações poderosas e um sistema político sobrecarregado por burocracias estatais, uma reforma pautada na boa administração e na responsabilidade pública nos diferentes domínios sociais (idem). São as associações voluntárias autogovernadas, constituídas, portanto, por mecanismos internos democráticos ${ }^{20}$. Para o autor, há um conjunto de necessidades individuais que não podem ser satisfeitas pela ação privada de indivíduos isolados, e certas liberdades que só podem ser perseguidas de maneira coletiva (como a melhoria e o maior controle no trabalho via sindicatos ou maior desenvolvimento das capacidades individuais via participação e

associativismo pelo viés do cooperativismo, do sindicalismo ou do corporativismo.

20 Em crítica às propostas de outros autores (entre eles Cohen e Rogers (1995)), Hirst alivia o forte papel dado ao Estado na formação de associações, o que pode gerar organizações fracas e dependentes, ao mesmo tempo empoderando ainda mais o próprio Estado; tratando-se, pois, de uma crítica central à proposta da democracia associativa. Para o autor, o objetivo do Estado é o de promover políticas que empoderem as associações e que devolvam a elas várias atividades públicas (na esfera econômica e social) para o exercício democrático. Assim, diferente da ação do Estado, há que se pensar em formas alternativas de construção de associações desde baixo, fundamentalmente por meio das associações mais fortes, das igrejas, dos sindicatos e outros atores sociais. Da mesma forma, a democracia associativa deve ser construída desde baixo (HIRST, 2001, p. 37-41). 
cooperação). De acordo com essa perspectiva, a resolução do impasse dado pela centralização da provisão dos serviços sociais pelo Estado (centralizado e burocratizado) ou pelo mercado passaria, portanto, pela devolução da provisão de direitos e serviços de bem estar social para as associações voluntárias. Compete ao Estado garantir fundos públicos que permitam que os cidadãos, e não os burocratas, escolham e participem na formulação e na oferta desses bens e serviços (idem, p. 185). Como resultado, o autor vislumbra uma sociedade cooperativa e plural, cabendo ao Estado a garantia e manutenção desse sistema, além de preservar sua responsabilidade e controle em certos domínios que são comuns a todos os membros da sociedade, como, por exemplo, os direitos individuais, a defesa de seu território, certos poderes de polícia e provisões nas áreas da saúde e meio ambiente. Mantém-se, nessa proposta, o papel do Estado e da classe política em incentivar e promover a descentralização dos espaços e do poder por meio das diferentes agências de controle, cobrança de impostos, fiscalização, elaboração de marcos regulatórios, entre outros ${ }^{21}$.

Cohen e Rogers (1995) também compartilham com o ideário associativista e dialogam com perspectivas liberais, republicanas e pluralistas que apontam críticas, sob diferentes graus e perspectivas, centradas nas ameaças advindas de uma maior aproximação, das associações, com o poder político. Na listagem de problemas que são apontados por essas frentes analíticas, os autores ressaltam os riscos de facciosismo, da balcanização de interesses no interior do Estado, de seu domínio por determinados grupos da sociedade, e da sua ineficiência frente à sobrecarga das demandas sociais organizadas (idem). Entretanto, embora reconheçam contribuições dessas diferentes vertentes, os autores advertem que todas elas falham na visão da importância dos grupos e das associações, na medida em que não avaliam as suas variações qualitativas e a sua dimensão artefatual (idem).

\footnotetext{
21 O autor desenvolve o que denomina de "architecture of an associationalist commonwealth" definindo as instâncias e os papéis dos diferentes setores, parlamento, poder Executivo e poder Judiciário, nesse processo complexo de financiamento e de responsabilidades públicas (idem, p. 189190).
}

Para esses autores, ao contrário de ameaças à democracia, as relações entre as associações e o Estado permitem a promoção do ideal do bem comum, configurando um processo de soma positiva por meio do aumento do poder das associações e da maior eficiência do Estado e do mercado, o que promoveria o fortalecimento da ordem democrática (COHEN \& ROGERS, 1995). É nessa perspectiva que os autores apontam pelo menos quatro funções que, por serem preenchidas pelas associações, justificam a importância da democracia associativa frente aos problemas e desafios colocados pela complexidade social. Por um lado, pelo fato de sua maior proximidade com os problemas e maior conhecimento da realidade em que estão inseridas, as associações são recursos imprescindíveis de produção e de oferta de informações, consideradas centrais para a qualificação e clarificação das deliberações e decisões políticas. As associações também preenchem com os requisitos democráticos da equalização da representação política, ao proporcionarem oportunidades de explicitação de vozes e demandas aos indivíduos e setores com menos recursos e poder, e que tradicionalmente têm sido excluídos da representação política eleitoral de base territorial (idem, p. 43). Além disso, e seguindo a tradição participacionista, as associações podem funcionar como "escolas de democracia", desenvolvendo virtudes cívicas, competências políticas e autoconfiança, e promovendo o valor básico do reconhecimento das normas democráticas. Por último, as associações são centrais para a conformação de uma "governança alternativa". Aqui, para além de representarem interesses, as associações preencheriam funções "quase-públicas" na suplementação de fornecimento de serviços públicos, promovendo, por meio da cooperação e da confiança, melhor performance econômica e aumento da eficiência estatal. Com efeito, para esses autores, a democracia associativa requer um papel ativo das associações, participando diretamente nos espaços e instituições voltadas para a formulação das políticas, a coordenação das atividades econômicas, e o revigoramento e a administração das políticas públicas (idem, p. 55).

Duas dimensões são centrais nessa abordagem da democracia associativa e que justificam a elaboração de uma proposta democrática que prevê uma atuação mais ousada por parte do Estado (diferente, portanto, de Hirst) na adoção de uma 
política para as associações, para além da necessidade de reforma das próprias instituições políticas. A primeira dimensão diz respeito ao caráter da artefatualidade. De acordo com Cohen e Rogers (idem), diferente de serem fenômenos naturais, ou produtos da cultura ou de algum outro substrato inalterado da vida social (idem, p. 46), as associações são artefatos. Dependem das estruturas econômicas e políticas, dos recursos e das instituições nas quais estão inseridas. Podem variar de acordo com a maior centralidade ou não de governos, de informações disponíveis, das oportunidades e dos incentivos. Mudam de acordo com as escolhas políticas. Isso significa que o Estado tem um papel ativo e importante não apenas na reforma institucional, tendo em vista incorporar as associações nos processos de discussão, de formulação e de execução de políticas, como na própria formação das associações, provocando e incentivando de maneira mais incisiva, agindo diretamente no meio ambiente associativo no sentido de evitar a formação de facções e estimular, por meio de taxas, subsídios e sanções legais, o desenvolvimento de associaçãos respeitosas das normas democráticas igualitárias (idem).

A segunda dimensão aponta para o caráter qualitativo das associações. Tendo em vista enfrentar os argumentos que sustentam os riscos das facções, das diferenças de recursos e de poder no interior do campo asssociativo, essa dimensão procura delimitar determinadas características da vida associativa interna tendo em vista extrair os elementos que fazem diferença sob o ponto de vista do ideal democrático. Assim, partindo do pressuposto de que os grupos e as associações diferem em seus padrões de decisão interna, na sua maior ou menor capacidade de inclusão de membros, nas suas relações com outras associações, na natureza e extensão de seu poder e no escopo de suas funções e responsabilidades ${ }^{22}$, os autores descartam uma visão que generaliza o campo das associações, apontando seletivamente para aquelas que preencheriam as qualidades sugeridas pelo modelo, a exemplo de sindicatos e outras associações com representação mais ampla de setores sociais.

22 Os autores apresentam uma lista de sete traços que variam desde a accountability interna até o caráter de relações com o Estado (COHEN \& ROGERS, 1995, p. 48$50)$.
Assim, de modo geral, de acordo com Perczynski (1995), os diferentes autores da vertente da democracia associativa compartilham a tese de que as associações são cruciais para a representação dos interesses dos que não são suficientemente organizados por meio do sistema eleitoral territorial ${ }^{23}$. No entanto, para esse autor, se Paul Hirst segue uma tradição pluralista, na medida em que valoriza a pluralidade dos grupos e associações enquanto substratos da vida social e relativiza o papel do Estado na constituição da vida associativa, Cohen e Rogers, embora também valorizem a perspectiva pluralista, apresentariam traços mais marcantes da tradição corporativista, com destaque às associações mais abrangentes de defesa de amplos setores sociais, como sindicatos e associações profissionais, e ao papel ativo do Estado na própria organização das associações e nas relações entre elas (idem, p. 78).

Em que pese essas diferenças, seja com relação aos tipos de associação, seja com o papel do Estado ou às propostas de reforma política, a vertente teórica da democracia associativa extrai, do campo da organização associativa, uma forte responsabilidade pública, construindo uma base argumentativa ancorada na tese de que as associações são soluções - possíveis e democráticas - para lidar com a administração da complexidade social. Associações provêem informações, contribuem para a inclusão política e, fundamentalmente, ajudam os governos a administrarem a sociedade em contextos de complexidade social. Nessa vertente teórica, o foco na participação direta das associações no exercício de funções deliberativas e de administração e provisão de serviços públicos almeja garantir uma maior eficácia e accountability na formulação e no gerenciamento da coisa pública, realizando, portanto, o avanço democrático pautado na cooperação, na igualdade política e na eqüidade distributiva.

23 Assim como o orçamento participativo pode servir de exemplo de democracia participativa, em especial pelo fato de estar assentado na participação individual, os Conselhos Gestores podem ser considerados exemplos de democracia associativa, na medida em que, nesses espaços, a participação institucional ocorre sob prerrogativas legais que determinam a representação por meio de associações, organizações ou "entidades sociais", fundamentalmente daquelas que atuam ou que contam com algum reconhecimento nas respectivas áreas de intervenção governamental. 
Entre as críticas dirigidas a essa proposta, destaco àquelas relativas ao tipo de associação elencadas como boas para a democracia, às relações de poder no campo associativo e ao papel do Estado nesse processo.

No que diz respeito ao tipo de associações sugeridas por Cohen e Rogers, Young (1995, p. 210) chama a atenção para o fato da necessidade de se fazer distinções entre associações e grupos sociais, na medida em que, para a autora, se uma associação é uma instituição formalmente organizada (como um clube, corporação, partido político, igreja ou sindicato), os grupos sociais são menos artefatuais, ou mais "naturais", na sociedade. Embora sejam construídos socialmente e sejam mutáveis, não se constituem por meio de decisões explícitas ou por meio de políticas institucionais. Apresentam afinidades de experiências similares de tipo de vida e são também atores centrais para a política e a democracia, a exemplo dos grupos organizados pelo recorte de gênero, etnia, raça, religião e orientação sexual (idem, p. 209). A incorporação desses grupos e associações no modelo associativo permitiria, de acordo com a autora, a inclusão desses setores nos processos de decisão e de execução de políticas, ampliando e pluralizando os espaços e atores de poder e rompendo com as diferentes práticas de discriminação e injustiça social.

Por outro lado, a ênfase dada ao caráter cooperativo junto aos governos é questionada, por exemplo, por Szasz (1995, p. 148) ao resgatar a importância dos movimentos sociais e sua atuação conflitiva frente aos poderes instituídos. Para além do reconhecimento de associações (e movimentos sociais) de caráter contestador, ressalta-se também as relações de poder no interior desse campo de relações sociais. Aqui, os problemas de oligarquização no tecido associativo ameaçam processos pautados nos princípios da igualdade $\mathrm{e}$ da pluralidade (BADER, 1995). Da mesma forma, aponta-se problemas relativos às relações com o Estado, seja pelos receios de cooptação, seja pelos riscos, tanto da "feudalização" do Estado por determinados grupos sociais, como da transferência das responsabilidades do Estado para a sociedade, gerando políticas fragmentadas, particularizadas e desiguais, e rompendo com a dimensão dos direitos individuais universais (ROBTEUTSCHER, 2000).

\section{DEMOCRACIADELIBERATIVA: SOCIEDADE CIVIL, ESFERAPÚBLICAE ASSOCIAÇÕES}

No conjunto das abordagens teóricas que visam o aprofundamento da democracia, a democracia deliberativa tem se constituído, nas últimas duas décadas, como a perspectiva dominante nesse debate (DRYZEK, 2003; ELSTUB, 2008). Os democratas deliberativos entendem, de maneira geral, que a democracia repousa no ideal de justificação do exercício do poder político por meio da discussão pública entre indivíduos livres e em condições iguais de participação. De acordo com Thompson (2008), o núcleo de todas as concepções da democracia deliberativa está composto por aquilo que é denominado de requerimento de dar razão, ou seja, espera-se que tanto os cidadãos quanto os seus representantes justifiquem as demandas políticas e a elaboração de leis por meio de procedimentos igualitários e inclusivos de troca de argumentos adequados e voltados para a formação de opiniões bem informadas. No entanto, se há um consenso entre os democratas deliberativos em sua rejeição à limitação da democracia como modelo que se apóia sobre as ideias de interesse individual, agregação de preferências e competição política, as diferenças apontam para diversas questões, como o entendimento acerca do significado de razão adequada, a extensão dos foruns deliberativos ou a desejabilidade do consenso como meta (idem, p. 498). Nesse debate, há também diferenças sobre os locus e os atores deliberativos. Embora as instituições da democracia representativa figurem como o locus central de debate e de definição das questões públicas, elas não são suficientes para gerar poder legítimo. De diferentes maneiras, estudiosos resgatam a importância das associações, com especial atenção aos movimentos sociais, nesse processo ${ }^{24}$.

Tendo em vista superar os problemas da legitimidade da autoridade política nas sociedades complexas e plurais, nas quais processos de justificação das decisões políticas não derivam de uma concepção substantiva do bem comum compartilhada por todos os cidadãos, e nem de

\footnotetext{
24 Diferente de práticas e experiências que estão baseadas na participação dos cidadãos, como as pesquisas de opinião deliberativa que têm sido coordenadas por Fishkin e colaboradores. Cf. Fishkin e Luskin (2000) e Fishkin e Rosell (2004).
} 
procedimentos legais desacoplados da vontade e da opinião democráticas, Habermas (1997; 2005) aponta os processos deliberativos, caracterizados pela formação e troca de opiniões - por meio de discursos racionais sob condições que oportunizem a inclusão dos afetados, de direitos iguais de fala, de ausência de repressão ou manipulação e pautado pela sinceridade e reciprocidade - como a base democrática da legitimidade política. Reconhecendo a pluralidade social e os limites sistêmicos dados pelo processo de diferenciação funcional que caracteriza as sociedades complexas, essa proposta deliberativa advoga que a formação de opiniões ocorre em uma variedade de esferas públicas que, desprovidas de sujeitos ${ }^{25}$, conformam uma infraestrutura formada por processos de filtragem, a qual permite a circulação e a transformação das ideias e opiniões por meio de procedimentos comunicativos que partem das redes informais da esfera pública e atravessam os corpos legislativos e governamentais.

Nessa perspectiva, Habermas (1997) aponta para uma dupla dinâmica do processo deliberativo, qual seja, a deliberação informal que ocorre na esfera pública que, por seu turno, influencia a deliberação formal dada nos espaços políticoinstitucionais. Esses diferentes espaços - a esfera pública informal e as instituições políticas e governamentais - exercem papéis distintos e complementares para a produção de decisões políticas legítimas. A comunicação informal que ocorre na esfera pública ${ }^{26}$ ocorre por meio de

25 Em contraste com modelos participativos que defendem o exercício da participação direta face a face, fundamentalmente nas escalas locais (DRYZEK, 2003). De acordo com Habermas, a concepção republicana pautada na ideia de que o "processo democrático depende das virtudes de cidadãos orientados para o bem comum" (HABERMAS, 1997, p. 44), apresenta um caráter de homogeneidade e virtuosidade que não condiz com uma realidade complexa e plural. O reconhecimento do pluralismo cultural e social, bem como dos conflitos de interesses sociais, estimula o autor a redefinir a democracia, deslocando o foco da cidadania virtuosa para o dos espaços públicos e dos procedimentos comunicativos. Ademais, de acordo com Habermas, há que se reconhecer os limites ou fronteiras entre o Estado e a sociedade, na medida em que compete ao primeiro a regulação e a administração dos problemas sociais.

26 De acordo com Habermas, "a esfera pública pode ser descrita como uma rede adequada para a comunicação de conteúdos, tomadas de posição e opiniões; nela os fluxos comunicacionais são filtrados e sintetizados, a ponto de se grupos, associações e organizações que estão mais próximas do mundo da vida ${ }^{27}$, o que permitiria, para o autor, detectar melhor os problemas, discuti-los em fóruns abertos e plurais e torná-los públicos, adensando os debates e demandas ao poder estatal. Esse processo, que se realiza na rede de comunicação dos espaços públicos, é o substrato da proposta deliberativa. Aqui, em vez do modelo individual de agregação das opiniões que caracteriza a perspectiva eleitoral, a instância geradora de poder legítimo é a esfera pública, fundamentalmente quando ocupada pelas organizações da sociedade civil que operam como sensores na identificação de problemas relevantes e na produção, contestação e interpretação de valores e demandas ancoradas em razões públicas e operadas pelo intercâmbio discursivo. Sem a intervenção e a participação da sociedade civil, esvazia-se o caráter democrático da formação de preferências, já que o "seu núcleo institucional é formado por associações e organizações livres, não estatais e não econômicas [...] que captam os ecos dos problemas sociais que ressoam nas esferas privadas, condensam-nos e os transmitem, a seguir, para a esfera pública política" (idem, p. 99).

Nesse modelo democrático, a esfera pública política - instâncias da representação eleitoral e das agências estatais - figura como um segundo estágio, promovendo meios institucionais de regulação para o processamento das demandas e para deliberar sobre as propostas, avaliando as soluções alternativas e tomando decisões autorizativas sob condições justas de diálogo argumentativo em respeito aos pressupostos da pluralidade, condições de igualdade na participação e liberdade (COHEN, 1999a). Nessa dinâmica, a soberania do povo desloca-se para procedimentos de geração de um poder que "resulta das interações

condensarem em opiniões públicas enfeixadas em temas específicos" (1997, p. 92).

${ }^{27} \mathrm{Na}$ teoria da ação comunicativa, Habermas apresenta uma diferenciação entre sistema e mundo da vida como diagnóstico dos problemas contemporâneos. O sistema é composto por dois subsistemas: o Estado e o mercado. Os mecanismos de coordenação da ação nesses subsistemas são respectivamente o poder e o dinheiro, caracterizando, portanto, uma ação baseada na racionalidade estratégica e/ ou instrumental. Já o mundo da vida caracteriza-se pela ação comunicativa. Trata-se da esfera das tradições, da cultura compartilhada, da solidariedade e da cooperação. 
entre a formação da vontade institucionalizada constitucionalmente e esferas públicas mobilizadas culturalmente, as quais encontram, por seu turno, uma base nas associações de uma sociedade civil que se distancia tanto do Estado como da economia" (HABERMAS, 1997, p. 24).

Com efeito, cabe às associações da sociedade civil 28 a construção, na esfera pública, da formação da opinião e da vontade, influenciando o poder político institucional. Essa concepção "auto-limitada" da atuação política das associações, e, portanto, mais indireta, se comparada à vertente anterior, é objeto de questionamentos desenvolvidos por autores que visam operar maiores transformações nos espaços do poder político, seja reclamando um papel mais direto das associações nos espaços de poder, seja por ressaltarem uma atuação mais contestadora dos movimentos sociais, seja por assumirem a importância de ambos.

Para o primeiro caso, Joshua Cohen é uma referência central. De acordo com o autor, Habermas desloca o locus principal da participação da sociedade civil para a esfera pública informal, apontando para uma via na qual o público participa e atua na política, porém sem requerer encontros de participação direta entre o Estado e a sociedade. Para Cohen (1999b), três princípios são essenciais para a democracia deliberativa como estabelecimento de condições para a livre discussão racional entre cidadãos iguais, tendo em vista a autorização para o exercício do poder político: (i) o princípio de inclusão deliberativa, caracterizado pela ideia de que todos são cidadãos com os mesmos direitos, independentemente de sua

28 Habermas resgata o conceito de sociedade civil de Cohen e Arato (1992). Para esses autores, a sociedade civil é a esfera social ocupada por um conjunto de atores, organizações e relações que se diferenciam dos partidos e outras instituições políticas (uma vez que não estão organizados tendo em vista a conquista do poder), bem como dos agentes e instituições econômicas (não estão diretamente associados à competição no mercado). As associações, entre elas os movimentos sociais, são os principais atores da sociedade civil, na medida em que representam a pluralidade, a autonomia e a solidariedade, operando por lógicas de comunicação e de reciprocidade que procuram influenciar os sistemas político e econômico em direção à democracia. Assim, as associações e organizações autônomas, não estatais e não econômicas conformam o núcleo central do conceito de sociedade civil (HABERMAS, 1997). inserção social, política, religiosa, econômica e cultural. Trata-se, portanto, do respeito ao princípio do pluralismo; (ii) o princípio do bem comum, que diz respeito à possibilidade de um acordo público a respeito das prioridades sociais, tendo em vista a promoção de maior justiça social e (iii) o princípio da participação, caracterizado pela garantia de direitos iguais de participação, incluindo os direitos de votar, de associação, de expressão política, de ser eleito para um posto público e garantias de igualdade de oportunidades para o exercício de uma influência eficaz (idem, p. 38).

A combinação desses três princípios permite, segundo Cohen, uma concepção de democracia deliberativa que articule processos com resultados, e que faça valer de fato as expressões "pelo povo" e "para o povo" que são próprias do ideal de democracia. Entre o conjunto de sujeitos deliberativos, o autor destaca o papel das associações "secundárias" 29 , na medida em que representam os interesses de uma ampla base social que, de outra forma, encontra-se subrepresentada. A atuação desse associativismo é fundamental para corrigir as desigualdades econômicas subjacentes e garantir a competência regulatória requerida para a promoção do bem comum (COHEN, 2000).

Uma segunda abordagem, ao acusar uma confortável acomodação da atuação associativa ao Estado liberal na teoria habermasiana, aponta os movimentos sociais como os atores centrais para a construção de espaços deliberativos críticos às instituições existentes. Procurando ampliar as formas e os tipos de comunicação na proposta deliberativa, Dryzek (2003) enfatiza o papel dos discursos na esfera pública, porém com ênfase na contestação entre diferentes discursos antes do que no engajamento identitário. Nessa via interpretativa, reconhece-se a presença de diferentes e conflitantes discursos na esfera pública, sendo um erro supor o prevalecimento de discursos progressistas dados principalmente pelos novos movimentos sociais (idem, p. 76) embora esses sejam os protagonistas de sua

29 Enquanto grupos organizados que são intermediários entre o mercado e o Estado (COHEN, 2000, p. 43). Vemos, portanto, que o autor mantém as premissas acerca da importância das associações desenvolvidas na obra Associations and Democracy (COHEN \& ROGERS, 1995). 
proposta de "democracia discursiva", baseada na ideia de que os discursos contestadores da sociedade civil promovem a ampliação e o aprofundamento da democracia. A ênfase na atuação contestadora da sociedade civil na esfera pública aponta para as diferenças, por exemplo, com autores que enfatizam os processos deliberativos no estilo do "modelo universitário"30, na medida em que "a democracia discursiva não é um clube exclusivo de cavalheiros" (idem, p. 168) ${ }^{31}$. Constituindo a vida associativa autolimitada, ou seja, orientada pelas relações que estabelecem com o Estado, mas sem objetivos de conquista de poder, a sociedade civil é considerada o espaço de ação política mais autônomo e que melhor preenche, em comparação com os agentes estatais, as condições de uma democracia deliberativa autêntica, ancorada em processos comunicativos baseados na reflexão e na ausência de coerção. Dryzek apresenta algumas características da ação política (autolimitada, porém não desprovida de poder) da sociedade civil, como a capacidade de promover mudanças nos discursos políticos e que afetam as políticas públicas, e mudanças na cultura política e no campo da ética e dos comportamentos, a exemplo do movimento feminista e das organizações ambientalistas. Ocupando um lugar central na arquitetura da democracia deliberativa por gerar legitimidade democrática, a esfera pública (DRYZEK \& NIEMEYER, 2008) é o lugar da atuação das associações com menos risco de absorção ou cooptação ${ }^{32}$.

\footnotetext{
30 De acordo com Budge (2000), no modelo universitário, uma proposta temática é apresentada e detalhada aos participantes de um fórum, que criticam e apresentam contrapropostas. Resultados relevantes são sumarizados e, sob o encorajamento do debate por um moderador competente, expõe-se as conclusões acerca da opinião coletiva formada, tudo sob controle tendo-se em vista a melhor aproximação com o ideal de fala, a exemplo da igualdade e do respeito mútuo. Um exemplo são as "pesquisas de opinião deliberativas" (FISHKIN \& LUSKIN, 2000; FISHKIN \& ROSELL, 2004).

31 Embora mais recentemente, o autor (cf. DRYZEK \& NIEMEYER, 2008) proponha a formação de "câmaras de discursos" como formato de representação deliberativa.

32 Entendida como processo de incorporação de setores ou lideranças dos movimentos sociais na estrutura política, tendo em vista impedir as ameaças à estabilidade do sistema, sem efetivo compartilhamento de poder (DRYZEK, 2003, p. 88).
}

Uma perspectiva mais articulada, no sentido de reconhecer diferentes funções democráticas das associações, pode ser encontrada em Young (2003) que também endossa, embora apontando várias críticas, procedimentos deliberativos pautados na premissa da inclusão democrática. Ao procurar romper o ciclo desenhado pelas relações entre as desigualdades sociais e econômicas estruturais e a exclusão política, a autora, para além de ampliar o leque de possibilidades e formas comunicativas nos processos deliberativos, incluindo, por exemplo, a saudação, a narrativa e a retórica ${ }^{33}$, e de apontar a necessidade de rediscutirse a dimensão da representação política, tornandoa mais inclusiva frente a pluralidade e a complexidade das sociedades de massa atuais ${ }^{34}$, resgata as dimensões conflitivas da democracia mediante a valorização das lutas dos grupos ativistas que denunciam as injustiças sociais ${ }^{35}$. A ideia de esfera pública é aqui também central, e está relacionada com o engajamento e as lutas sociais de protesto e de oposição às relações de desigualdade e de discriminação. Assim, defendendo um modelo descentrado de sociedade, caracterizado pela constituição de variados lugares, instituições e práticas de ação e comunicação políticas, a autora também dá destaque aos processos de discussão, organização e participação das associações da sociedade civil na esfera pública, vistos como importantes ferramentas de oposição, publicitação e de controle do poder pelos cidadãos organizados

\footnotetext{
33 De acordo com Young (2003), a ênfase no argumento (entendido como cadeia ordenada de raciocínio pautado na imparcialidade, objetividade, universalidade e na racionalidade) de ideal de comunicação deliberativa, impede, limita e exclui a participação e a voz dos setores oprimidos e marginalizados. Trazer à cena do debate público outras formas de comunicação é, portanto, um elemento central para a promoção do ideal de inclusão democrática.

34 Propondo a representação de grupos por meio da ideia de "perspectiva social" tendo em vista a inclusão política de setores excluídos e marginalizados (idem).

35 Analisando diferenças, aproximações e tensões entre a perspectiva ativista e a deliberativa, Young (2001) chama a atenção não apenas para a importância das duas formas de engajamento político em sociedades descentradas, como das contribuições críticas da democracia ativista para a prática e a teoria da democracia deliberativa, não apenas no sentido de pressionar para a publicidade a inclusividade, como no sentido de fazer prevalecer, nos espaços deliberativos, a discussão de questões que tocam a fundo nas desigualdades sociais e econômicas estruturais.
} 
(idem). Para a autora, uma sociedade civil ativa, autônoma e diversificada é central para a democracia, na medida em que a comunicação operada pela vida associativa promove organização e interação grupal, permite a expressão pública de demandas e problemas sociais e promove a inclusão democrática, especialmente dos grupos e setores historicamente excluídos dos processos e mecanismos de representação política. Por outro lado, e como apontado anteriormente, em concordância com algumas assertivas da democracia associativa, as associações também exercem um papel mais ativo na promoção de espaços e atividades de interação com o Estado, como a implementação ou execução de políticas públicas, por exemplo. Entretanto, o reconhecimento das tensões que caracterizam esses diferentes campos de ação e de organização social serve de alerta para os constantes riscos de controle e perda de autonomia e de capacidade crítica e contestadora do campo associativo.

Assim, em que pese também a variedade e as diferenças de enfoque e de perspectivas, o papel de destaque dado às associações, para essa vertente teórica, está diretamente relacionado à idéia de esfera pública. Nesse sentido, o principal argumento acerca da importância democrática das associações está ancorado na tese de que as associações são os atores centrais da sociedade civil e responsáveis por tornar públicas e problematizar as demandas e problemas sociais. Associações e movimentos sociais promovem a legitimidade democrática ao alimentarem os debates e medidas tomadas pelas instituições políticas, e desencadeiam engajamento e ativismo político, exercendo atividades de base propositiva e/ou contestatória, problematizando a relações de poder e as injustiças sociais.

Como analisa Warren (2001), esse conceito de sociedade civil apresenta uma dimensão setorial, constituindo-se como "o domínio da organização social na qual as relações de associação voluntária são dominantes" (idem, p. 56), o que impede de pensar a sociedade civil como um campo de práticas que estão baseadas em relações que interagem, de diferentes formas, com o Estado, o mercado e as relações de intimidade. Além disso, a exclusão das associações primárias ${ }^{36}$, por um lado, e das associações terciárias (como partidos e sindica-

36 De acordo com Warren (2001), essa definição segue um tos), por outro, empobrece o caráter heterogêneo que conforma esse campo social. Além da dimensão da heterogeneidade, aponta-se, nessa abordagem, a uma estilização analítica que separa, normativamente, sociedade civil e Estado, aquela vista como o campo das virtudes em contraposição ao Estado, entedido como esfera do poder e da razão instrumental (GURZA LAVALLE, 1999; 2003; DAGNINO, OLVERA \& PANFICHI, 2006). Ao caráter relacional soma-se a necessidade de resgatar a dimensão das desigualdades sociais. De acordo com Chambers e Kopstein (2001, p. 859) é bastante limitada uma concepção que enalteça a importância de boas associações e da expansão da esfera pública, com ênfase nos aspectos político-institucionais, sem considerar as condições socioeconômicas subjacentes, ou a dimensão das desigualdades sociais que influenciam o campo das relações associativas.

\section{CONCLUSÕES: TENSÕES E COMBINA- ÇÕES ENTRE PARTICIPAÇÃO, DELIBE- RAÇÃO E ASSOCIAÇÃO}

Embora as diferenças e especificidades, todas as três perspectivas da democracia questionam os limites da democracia liberal e buscam ampliar os sujeitos e os espaços da participação e da deliberação reconhecendo, por variados argumentos, o papel democrático das associações. No caso dos autores vinculados à democracia participativa, o principal argumento acerca da importância democrática das associações está ancorado na tese de que as associações são instrumentos que qualificam a participação direta dos cidadãos, verdadeira essência da democracia. Além de outros efeitos democráticos, as associações contribuem para a criação de espaços de participação e empoderam os indivíduos para uma participação mais ativa e qualificada junto às instituições participativas.

uso comum que exclui as relações íntimas entre famílias e amigos, consideradas de domínio "privado" ou "antipolítico", seguindo a perspectiva de Hannah Arendt. Nesses termos, de acordo com o autor, podemos entender por que o conceito de sociedade civil é inadequado para entendermos o terreno associativo da democracia. "É no âmbito das relações de intimidade que esperamos encontrar as disposições éticas de reciprocidade, empatia e de cuidados que, injetadas nos domínios políticos, podem assegurar a democracia. Concepções espaciais-setoriais obscurecem o que uma concepção relacional de associação torna óbvio" (idem, p. 57). 
Para a vertente da democracia associativa, as associações são soluções - possíveis e democráticas - para lidar com a administração da complexidade social. Associações provêem informações, contribuem para a inclusão política e, fundamentalmente, ajudam os governos a administrarem a sociedade em contextos de complexidade social. O foco na participação direta das associações no exercício de funções deliberativas e de administração e provisão de serviços públicos pretende, para os expoentes dessa vertente, a garantia de maior eficácia e accountability na formulação e no gerenciamento da coisa pública, realizando, portanto, o avanço democrático pautado na cooperação, na igualdade política e na eqüidade distributiva.

Para alguns autores vinculados ao debate sobre a democracia deliberativa, e em que pese também, como nas perspectivas anteriores, a variedade $\mathrm{e}$ as diferenças de enfoque, o papel de destaque dado às associações está diretamente relacionado à ideia de esfera pública. Por gerar poder legítimo, atuar mais diretamente nos espaços decisórios ou por contestar relações de poder e injustiças sociais, $o$ fato é que, para esses autores, as associações e os movimentos sociais ocupam um lugar central no conceito de sociedade civil, fundamento central do aprofundamento democrático.

Assim, se tomarmos essas perspectivas no seu conjunto, podemos sugerir que a ampliação e o aprofundamento da democracia depende da articulação, não isenta de tensões, entre os pressupostos da participação, da deliberação e da associação. Tais pressupostos, quando vistos de maneira unilateral, apresentam algumas limitações frente à complexidade das sociedades contemporâneas.

A ênfase dada ao poder das associações no modelo da democracia associativa suscita importantes questões, para além das perguntas sobre o escopo e os critérios de escolha das associações e dos riscos de manipulação e de controle do Estado. Por exemplo, dado o peso à cooperação com o Estado e o mercado, Cohen e Rogers (1995) são criticados por negligenciarem o papel da sociedade civil e dos movimentos sociais no estabelecimento de conflitos e oposições necessários para a mudança social (SZASZ, 1995). Além disso, registram-se os riscos da transferência das responsabilidades do Estado para a sociedade, por meio de políticas fragmentadas, particularizadas e desiguais, rompendo com a dimensão dos direitos universais. Em vez de descentralização e pluralização de poder, a resultante pode ser a criação de novas relações baseadas na competição e na criação de sistemas incompatíveis e contraditórios entre si (ROBTEUTSCHER, 2000). Ademais, as possibilidades efetivas de captura dos processos de decisão política pelas associações mais poderosas colocam em risco as intenções de inclusão dos setores pauperizados e marginalizados, tradicionalmente excluídos das deliberações públicas (YOUNG, 1995).

No caso da abordagem "autolimitada da sociedade civil" desenvolvida pela perspectiva deliberativa, ressalta-se o caráter "sobrestimado" e "dicotomizado" das ações coletivas, por meio de uma perspectiva setorial que vê nestas o pólo da virtude, em contraposição ao Estado, esfera da dominação e da lógica instrumental (GURZA LAVALLE, 1999; 2003; DAGNINO, OLVERA \& PANFICHI, 2006). A heterogeneidade da sociedade civil constitui-se, entre outros, como elemento de questionamento acerca da excessiva carga normativa do conceito que, ancorado na dicotomia entre sistema e "mundo da vida", acaba obscurecendo as relações entre a sociedade e o Estado, ou entre a sociedade civil e a sociedade política. Dagnino, Olvera e Panfichi (2006) chamam a atenção para os diferentes tipos de relacionamento, sendo que a "heterogeneidade da sociedade civil e do Estado configura um mapa extraordinariamente complexo de possibilidades de colaboração e confronto" (idem, p. 38). Por outro lado, Silva e Zanata Jr. (2008) ressaltam como as perspectivas teóricas que carregam uma ênfase normativa no caráter igualitário e democratizante das organizações da sociedade civil têm dificultado as análises acerca das desigualdades no interior desse campo $^{37}$, e limitado a "capacidade de problematizar a relação dessas organizações com os processos de (re)produção das desigualdades no Brasil" (idem, p. 117). Seguindo esse caminho, Gurza Lavalle, Castello e Bichir (2008) apontam para o fato de que "pouco sabemos, por exemplo, das hierarquias internas e da capacidade de ação desiguais das organizações civis, da sua diferenciação funcional e das clivagens políticas e conflitos internos, em suma, do modus operandi da sociedade civil" (idem, p. 73).

37 Ver também Kerstenetzky (2003). 
Por outro lado, e apontando para uma perspectiva descentrada de política e de sociedade (YOUNG, 2003), se o reconhecimento de que participação direta, atuação associativa e implementação de espaços e procedimentos deliberativos, para além - e em articulação com os espaços de representação política eleitoral, conformam um quadro mais amplo, e, portanto, mais complexo e plural de atuação política e de inclusão democrática, há de se reconhecer certas tensões e contradições nessas possíveis combinações. No caso das tensões entre participação direta e deliberação, Fung e Cohen (2007), por exemplo, analisam como a qualidade da deliberação pode trazer prejuízo para a participação, da mesma forma que, inversamente, a expansão, seja no número de pessoas, seja de espaços e temas de controle popular direto, pode diminuir a qualidade da deliberação, na medida em que essa preza o debate qualificado ancorado em boas razões. Aponta-se também para as tensões entre o associativismo ativista e a deliberação. De acordo com Mutz (2006), para a democracia deliberativa, a exposição a visões diferentes é ingrediente central na formação da opinião. Essa exposição beneficia os ocupantes da esfera pública, encorajando a troca de ideias e a reflexão necessárias para a formação das opiniões e para a superação de visões parciais ou paroquiais (idem, p. 8). Além disso, há uma relação direta com a dimensão da legitimidade, uma vez que nenhum pensamento individual pode antever a variedade de perspectivas necessárias para uma decisão democrática legítima. Ou seja, ouvir o outro lado tem sido central para a democracia, sendo que a exposição a visões diferentes é a razão de ser da deliberação política. Por outro lado, prossegue a autora, a participação e o ativismo político ocorrem em um ambiente no qual as pessoas pensam igual. Com efeito, "pessoas que pensam da mesma forma incentivam uns aos outros para a ação coletiva e promovem o tipo de paixão e entusiasmo que são centrais para a motivação da participação política" (idem, p. 4). Há, portanto, tensões entre participação associativa e deliberação.
Apesar disso, combinações ou reconciliações entre maior participação, deliberação e associação prometem ser um caminho promissor para o avanço democrático. A tese do poder descen-trado sugere o reconhecimento de diferentes espaços e atores, e, fundamentalmente, tendo em vista sociedades baseadas em desigualdades sociais e econômicas estruturais, advoga pela importância de atores e espaços autônomos de exercício da crítica e da contestação política (YOUNG, 2003).

A ideia de "ecologia democrática das associações" (WARREN, 2001) parece seguir essa perspectiva de reconhecimento de diferentes (e em muitos casos conflitantes) atores e instituições que, no seu conjunto, constituem um complexo mosaico de práticas e orientações políticas e sociais. Por um lado, o reconhecimento de que diferentes tipos de associações podem provocar diferentes efeitos democráticos permite um olhar mais amplo para as diversas possibilidades - e limites - das práticas associativas, ao mesmo tempo em que evita de esperar-se que as associações combinem todas as virtudes democráticas, sendo, ao mesmo tempo, deliberativas, representativas, contenciosas, cultivadoras de virtudes cívicas, formadoras de opinião etc.

Abrigados pelo princípio liberal dos direitos individuais e pela inevitabilidade do modelo de representação eleitoral, os diferentes argumentos aqui extraídos - da participação direta dos cidadãos; da governança democrática operacionalizada por e com as associações; da deliberação da sociedade civil na esfera pública; das práticas contestadoras dos movimentos sociais - permitem, no seu conjunto, ampliar e complexificar os espaços e as práticas políticas, adensando a democracia. Nessa perspectiva, uma sociedade democrática depende da articulação, não isenta de tensões, entre os pressupostos da participação, da representação e da deliberação, levados a cabo - em diferentes lugares e seguindo múltiplos caminhos - por indivíduos, associações e instituições.

Lígia Luchmann (ligia@cfh.ufsc.br) é Doutora em Ciências Sociais pela Universidade Estadual de Campinas (Unicamp) e Professora do Departamento de Sociologia e Ciência Política na Universidade Federal de Santa Catarina (UFSC). 


\section{REFERÊNCIAS BIBLIOGRÁFICAS}

ALMOND, G. \& VERBA, S. 1963. The Civic Culture. Princeton: Princeton University.

AVRITZER, L. 2002. Orçamento participativo: as experiências de Porto Alegre e Belo Horizonte. In: DAGNINO, E. (org.). Sociedade civil e espaços públicos no Brasil. São Paulo: Paz e Terra.

BADER, V. 2001. Problems and Prospects of Associative Democracy: Cohen and Rogers Revisited. In: HIRST, P. \& BADER, V. (eds.). Associative Democracy: The Real Third Way. London: F. Cass.

BAgGeTTA, M. 2009. Civic Opportunities in Associations: Interpersonal Interaction, Governance Experience and Institutional Relationships. Social Forces, Chapel Hill, v. 88, n. 1, p. 175-199, Sept.

BARBER, B. 1984. Strong Democracy. Participatory Politics for a New Age. Berkeley: University of California.

BUDGE, I. 2000. Deliberative Democracy versus Direct Democracy - Plus Political Parties! In: SAWARD, M. (ed.). Democratic Innovation. Deliberation, Representation and Association. London: Routledge.

CHAMBERS, S. \& KOPSTEIN, J. 2001. Bad Civil Society. Political Theory, Thousand Oaks, v. 29 , n. 6 , p. 837-865, Dec.

COHEN, J. 1999a. Reflections on Habermas on Democracy. Ratio Juris, Oxford, v. 12, n. 4, p. 385-416, Dec. Disponível em: http:// dspace.mit.edu/bitstream/handle/1721.1/5452/ Ratio-Juris-Vol12-No4.pdf. Acesso em: 24.out.2012.

1999b. Deliberation and Democratic Legitimacy. In: BOHMAN, J. \& REGH, W. (eds.). Deliberative Democracy. Essays on Reason and Politics. Cambridge (MA): MIT.

2000. Procedimiento y sustancia en la democracia deliberativa. Metapolítica, Ciudad del México, v. 4, n. 14, p. 24-47, abr.-jun.

COHEN, J. \& ARATO, A. 1992. Civil Society and Political Theory. Cambridge (MA): MIT.

COHEN J. \& ROGERS, J. 1995. Associations and Democracy. London: Verso.
COOLEY, C. H. 1983. Human Nature and Social Order. Piscataway: Transaction.

DAGNINO, E.; OLVERA, A. J. \& PANFICHI, A. 2006. Para uma outra leitura da disputa pela construção democrática na América Latina. In: DAGNINO, E.; OLVERA, A. J. \& PANFICHI, A. (orgs.). A disputa pela construção democrática na América Latina. São Paulo: Paz e Terra.

DRYZEK, J. 2003. Deliberative Democracy and Beyond. Liberals, Critics, Contestations. Oxford: Oxford University.

DRYZEK, J. \& NIEMEYER, S. 2008. Discursive Representation. American Political Science Review, Los Angeles, v. 102, n. 4, p. 481-493, Nov.

ELSTUB, S. 2007. Overcoming Complexity: Institutionalising Deliberative Democracy through Secondary Associations. The Good Society, College Park, v. 16, n. 1, p. 14-22.

2008. Towards a Deliberative and Associational Democracy. Edinburg: Edinburg University.

FEDOZZI, L. J. 1996. Do patrimonialismo à cidadania participação popular na gestão municipal: o caso do orçamento participativo de Porto Alegre. Porto Alegre. Dissertação (Mestrado em Sociologia). Universidade Federal do Rio Grande do Sul.

FISHKIN, J. \& LUSKIN, R. 2000. The Quest for Deliberative Democracy. In: SAWARD, M. (ed.). Democratic Innovation. Deliberation, Representation and Association. London: Routledge.

FISHKIN, J. \& ROSELL, S. 2004. Choice Dialogues and Deliberative Polls. National Civic Review, Denver, v. 93, n. 4, p. 55-63, Winter. Disponível em: http://www.viewpoint learning.com/wp-content/uploads/2011/04/ deliberative_democracy_w04.pdf. Acesso em: 18.out.2012.

FUNG, A. 2003. Associations and Democracy: Between Theories, Hopes, and Realities. Annual Review of Sociology, Palo Alto, v. 29, p. $515-539$. 
FUNG, A. \& COHEN, J. 2007. Democracia radical. Política \& Sociedade, Florianópolis, n. 11, out. Disponível em: http://www.google. c o m.br/url ? s a $=\mathrm{t} \& \mathrm{rct}=\mathrm{j} \& \mathrm{q}=\mathrm{de} \mathrm{m}$ ocracia $\% 20$ radica $\% 20$ fung $\&$ source $=$ web $\&$ $c d=1 \& c a d=r j a \& v e d=0 C C E Q F j A A \& u r l$ $=$ http $\% 3 \mathrm{~A} \% 2 \mathrm{~F} \% 2 \mathrm{Fwww}$.ufpel.edu.br\%2Fenp os $\% 2 \mathrm{~F} 2011 \% 2 \mathrm{Fanais} \% 2 \mathrm{Fpdf} \% 2 \mathrm{FCH} \% 2$ FCH_00386.pdf\&ei=tEaIUJ T_L aLs0QGD_YDABQ\&usg=AFQjCNEcjmA VZGswo7YSM2GB0O76Z7IEJg. Acesso em: 12.nov.2012.

FUNG, A. \& WRIGHT, E. O. 2001. Deepening Democracy: Innovations in Empowered Participatory Governance. Politics \& Society, Thousand Oaks, v. 29, n. 1, p. 5-42.

GURZA LAVALLE, A. 1999. Crítica ao modelo da nova sociedade civil. Lua Nova, São Paulo, n. 47, p. 121-135. Disponível em: http:// www.scielo.br/pdf/ln/n47/a07n47.pdf. Acesso em: 24.out.2012.

2003. Sem pena nem glória. O debate da sociedade civil nos anos 1990. Novos Estudos, São Paulo, n. 66, p. 91-109, jul. Disponível em: http://www.fflch.usp.br/dcp/assets/docs/ Adrian/2003NovosEstudos SemPena NemGloria.pdf. Acesso em: 24.out.2012.

GURZA laValle, A.; CASTello, G. \& BICHIR, R. M. 2008. Atores periféricos na sociedade civil. Redes e centralidades de organizações em São Paulo. Revista Brasileira de Ciências Sociais, São Paulo, v. 23, n. 68, p. 73-96, out. Disponível em: http:// www.scielo.br/pdf/rbcsoc/v23n68/ v23n68a06.pdf. Acesso em: 24.out.2012.

HABERMAS, J. 1997. Direito e democracia: entre facticidade e validade. V. 2. Rio Janeiro: Tempo Brasileiro.

2005. Concluding Comments on Empirical Approaches to Deliberative Politics. Acta Politica, Basingstoke, v. 40, n. 3, p. 384-392, Sept.

HELD, D. 1987. Modelos de democracia. Belo Horizonte: Paideia.

HIRST, P. 1994. Associative Democracy. New Forms of Economic and Social Governance. Amhertz: University of Massachusetts.
2001. Can Associationalism Come Back? In: HIRST, P. \& BADER, V. (eds.). Associative Democracy: The Real Third Way. London: F. Cass.

KERSTENETZKY, C. L. 2003. Sobre associativismo, desigualdades e democracia. Revista Brasileira de Ciências Sociais, São Paulo, v. 18, n. 53, p. 131-152. Disponível em : http:/ /www.scielo.br/pdf/rbcsoc/v18n53/ 18082.pdf. Acesso em: 24.out.2012.

LÜCHMANN, L. H. H. 2011. Abordagens teóricas sobre o associativismo e seus efeitos democráticos. Trabalho apresentado no $15^{\circ}$ Congresso Brasileiro de Sociologia, realizado em Curitiba, de 26 a 31 de julho. Digit.

LÜCHMANN, L. H. H. \& BORBA, J. 2008. Participação, desigualdades e novas institucionalidades: uma análise a partir de instituições participativas em Santa Catarina. Ciências Sociais Unisinos, São Leopoldo, v. 44, n. 1 , p. 58-68.

MACPHERSON, C. B. 1978. A democracia liberal: origens e evolução. Rio de Janeiro: J. Zahar.

MUTZ, D. C. 2006. Hearing the Other Side. Deliberative versus Participatory Democracy. New York: Cambridge University.

PATEMAN, C. 1992. Participação e teoria democrática. Rio de Janeiro: Paz e Terra.

PERCZYNSKI, P. 1995. Associo-Deliberative Democracy and Qualitative Participation. In: COHEN, J. \& ROGERS, J. (eds.). Associations and Democracy. London: Verso.

PUTNAM, R. 1995. Bowling Alone: America's Declining Social Capital. Journal of Democracy, Baltimore, v. 6, n. 1, p. 65-78, Jan. Disponível em: http://xroads.virginia.edu/ $\sim$ HYPER/DETOC/assoc/bowling.html. Acesso em: 9.out.2012.

1996. Comunidade e democracia: a experiência da Itália moderna. Rio de Janeiro: Fundação Getúlio Vargas.

ROB TEUTSCHER, S. 2000. Associative Democracy - Fashionable Slogan or Constructive Innovation? In: SAWARD, M. (ed.). Democratic Innovation. Deliberation, Representation and Association. London: Routledge. 
SCHUMPETER, J. 1984. Capitalismo, socialismo e democracia. Rio de Janeiro: J. Zahar.

SILVA, M. K. \& ZANATA JR, R. 2008. Desigualdade e associativismo: proximidade espacial e distância social na conformação da sociedade civil. Revista Brasileira de Estudos Urbanos e Regionais, v. 10, n. 2, p. 115-131. Disponível em: http://www.anpur.org.br/ revista/rbeur/index.php/rbeur/article/ download/203/187. Acesso em: 12.nov.2012.

SZASZ, A. 1995. Progress Through Mischief: The Social Movement Alternative to Secondary Associations. In: COHEN, J. \& ROGERS, J. (eds.). Associations and Democracy. London: Verso.

THOMPSON, D. 2008. Deliberative Democratic Theory and Empirical Political Science. Annual Review of Political Science, Palo Alto, v. 11, p. 497-520, June.

URBINATI, N. \& WARREN, M. 2008. The Concept of Representation in Contemporary Democratic Theory. Annual Review of Political Science, Palo Alto, v. 11, p. 387-412, June.
VERBA, S. \& NIE, N. 1972. Participation in America: Political Democracy and Social Equality. New York: Harper \& Row.

WARREN, M. 2001. Democracy and Association. Princeton: Princeton University.

2008. Citizen Representatives. In: WARREN, M. E. \& PEARSE, H. (eds.). Designing Deliberative Democracy. The British Columbia Citizen's Assembly. Cambridge (UK): Cambridge University.

YOUNG, I. M. 1995. Social Groups in Associative Democracy. In: COHEN, J. \& ROGERS, J. (eds.). Associations and Democracy. London: Verso.

2001. Activist Challenges to Deliberative Democracy. Political Theory, Thousand Oaks, v. 29 , n. 5, p. 670-690, Oct. Disponível em: https://www.ucalgary.ca/peacestudies/files/ peacestudies/Young\%20-\%20Day\%202.pdf. Acesso em: 25.out.2012.

2003. Inclusion and Democracy. Oxford: Oxford University. 

This document was created with Win2PDF available at http://www.win2pdf.com. The unregistered version of Win2PDF is for evaluation or non-commercial use only. This page will not be added after purchasing Win2PDF. 